\title{
Microparticulate diets as first food for gilthead sea bream larva (Sparus aurata): study of fatty acid incorporation
}

\author{
J. H. Robin * and B. Vincent
}

Fish Nutrition Laboratory INRA-IFREMER, Centre de Brest de L'IFREMER, BP 70, 29280, Plouzané, France

*: Corresponding author : jrobin@ifremer.fr

\begin{abstract}
Recent advances have led to the development of inert diets for first-feeding marine fish larvae. The purpose of the present study was to evaluate fatty acid (FA) incorporation into larva using practical-type and semipurified diets as first food for larvae. Experimental microparticulate diets were fed to gilthead sea bream larvae, right from the mouth opening to day 21 post hatching. Five basal diets were compared, using fish meal or casein as main protein sources, and fish protein concentrate or casein hydrolysates and algae powder (Schizochytrium). Diets contained soybean lecithin to provide polar lipids and this also provided a high linoleic acid (18:2n-6) content. n-3 HUFA (1.5-1.7\% DM) were mainly in dietary neutral lipids, with a part in polar lipids in diets containing fish meal or fish hydrolysates. Fatty acid incorporation was studied by analysing FA content of larvae at the beginning and at the end of the trial.

A semipurified diet (casein+Schizochytrium powder) led to the best mean survival rate of $25 \%$ at day 21. While length increments were low, basal diets containing fish meal gave higher growth in size than casein-based diets. Whole body total fatty acid content differed between treatments and was higher in larvae fed casein-based diets than in those fed fish meal-based diets. As a result, fatty acid profiles shown showed various differences between treatments but not clearly related to dietary fatty acids. No clear sign of desaturation nor elongation of fatty acids was observed; the presence of 22:5n-6 (from Schizochytrium) into some diets did not seem to induce retroconversion to $20: 4 n-6$ by larva. Fatty acid profiles incorporated into larvae were compared to those of diets in order to display common tendencies: the incorporation of $n-6$ fatty acids was higher than their relative proportion in the diets, even for 18:2n-6 despite high dietary supply; incorporation of 20:4n-6 was two- to fourfold higher than the proportion in diets (irrespective of the level of 22:5n-6). Among saturated FA, high stearate but low myristate incorporation was observed. Taking into account the high level of n-3 HUFA in the larvae before first feeding, $\mathrm{n}-3$ long-chain PUFA were not selectively incorporated into larvae during feeding, with a negative tendency for EPA, and variable incorporation of DHA between treatments.
\end{abstract}

Keywords: Fish; Larva; Fatty acids; Inert diet; Sparus aurata 


\section{Introduction}

The development of inert diets, allows for the production of some marine fish larvae such as European sea bass without live prey (Cahu and Zambonino-Infante, 2001). For gilthead sea bream larva, inert diets have been successfully used in co-feeding with live prey (Koven et al., 2001). In early stages, at least a few days of feeding live prey is always needed before obtaining growth with microcapsules as food (Yúfera et al., 2000). With live prey improvement of growth and survival have been obtained by using enrichment of high levels of n-3 highly unsaturated fatty acids (HUFAs). Various estimations of the n-3 HUFA requirement for gilthead sea bream have been published. The estimated requirement could be overestimated, when Artemia where used which have low DHA/EPA ratio as shown by Rodriguez et al. (1993, 1998). Dietary HUFAs are also more efficient when present in polar lipids (PL) rather than in neutral lipids (Salhi et al., 1999). These two studies estimated minimal n-3 HUFA dietary requirements around $1.5 \%$ of dry weight, greater than the value estimated by Koven et al. (1990) at $0.5 \%$ for gilthead sea bream larva during first feeding with rotifers. Arachidonic acid was also shown to be required by this species (Bessonard et al., 1999)

The importance of dietary polar lipids for lipid utilisation by larva have been demonstrated by various studies (Kanazawa, 1993; Geurden et al., 1995; Koven et al., 1998). Phospholipid influence is particularly pronounced in early stages (Koven et al., 2001). Addition of soybean lecithin leads to improvement of inert diets for carp (Radunz-Neto et al., 1994), but this source is not suitable in fatty acid content for marine fish, with high levels of linolenic acid $(18: 2 \mathrm{n}-6)$ and no HUFAs. The aim of the present study was to use an inert diet as a first food for gilthead sea bream larvae, using basal diets developed for European sea bass and common carp, with high soybean lecithin content. The fatty acid incorporation into larvae was particularly followed. 


\section{Material and methods}

\subsection{Experimental fish and diets:}

A spawn of gilthead sea bream (Sparus aurata) larvae was obtained from "Ferme marine du Douhet" (La Brée les Bains, France). At complete hatching larvae were randomly distributed in 351 cylindroconical tanks (2800 larva per tank). Water temperature was maintained at $20^{\circ} \mathrm{C}$ with running seawater UV treated and filtered at $5 \mu \mathrm{m}$.

Larva were kept under darkness until the mouth opening occurring at day 3 post hatch (dph), then light was progressively increased until 600 lux. Diets, three replicates per treatment, were distributed at $1.5 \mathrm{~g} \mathrm{tank}^{-1} \mathrm{day}^{-1}$ continuously with automatic feeders. Excess feed, deposited on tank bottom, was removed daily by siphoning. Dead larvae were counted daily. At the end of the experiment larvae were made to fast overnight. Samples of 30 larvae per tank were anaesthetised in diluted phenoxyethanol and measured under a microscope from the beginning of jaws to the cord end. Another sample of 30 larvae was preserved in 5\% formalin and weighted, then the larvae were dried in an oven at $110^{\circ} \mathrm{C}$ during $24 \mathrm{~h}$ for a dry weight measurement. Remaining larvae were counted and samples of a known quantity were stored at $-80^{\circ} \mathrm{C}$ until analysis.

Five diets were prepared using ingredients presented in Table 1, and pelletized according to Fontagné et al. (2000). Ingredients were finely ground below $100 \mu \mathrm{m}$, and mixed before addition of oil and water. The most blend was pelletized $(3 \mathrm{~mm})$ using a meat grinder. Pellets were dried on air flux at $50^{\circ} \mathrm{C}$ during 20 minutes, ground and sieved in order to obtain 50 $160 \mu \mathrm{m}$ particles. Diets A, B, and C used fish meal and fish hydrolysate as protein sources, (autolysates differing between diet A and B); Diet D used casein and fish hydrolysate as protein sources (Carvalho et al, 1997), while diet E used casein, casein hydrolysate and 
sodium salt as descrided in Radunz-Neto et al. (1994). Diets C, D, E contained algamac, a micro algal powder of spray-dried Schizochytrium rich in DHA also containing 22:5n-6.

A high phospholipid quantity was provided by soybean lecithin, leading to a ratio of polar to neutral lipid near 1. Fish oil and olive oil were used to adjust n-3 HUFA at 2\% DM, however actual quantities were lower (Table 2). 
Table 1 : components (\%) and composition of experimental diets

\begin{tabular}{|c|c|c|c|c|c|c|}
\hline & diets & A & B & $\mathrm{C}$ & D & $\mathbf{E}$ \\
\hline \multicolumn{7}{|c|}{ Ingredients ${ }^{\mathrm{a}}$ (g 100 $\mathrm{g}^{-1}$ dry weight) } \\
\hline Fish meal Norse LT 94 & & 56 & 55 & 40 & - & - \\
\hline Fish hydrolysate CPSP-G & & 14 & - & - & - & - \\
\hline Fish hydrolysate CPSP-90 & & - & 14 & 15 & 30 & - \\
\hline Algamac $\AA 2000$ & & - & - & 8 & 8 & 14 \\
\hline Casein & & - & - & 7 & 23 & 32 \\
\hline Casein hydrolysate & & - & - & - & - & 5 \\
\hline Caseinate sodium salt & & - & - & - & - & 10 \\
\hline Dextrin & & - & - & - & 9 & 10 \\
\hline Soybean lecithin & & 12 & 12 & 12 & 12 & 9 \\
\hline Cod liver oil & & 5 & 3 & - & 1,4 & 3 \\
\hline Olive oil & & - & 2 & 5 & 3 & 2 \\
\hline Vitamin mixt ${ }^{\mathrm{b}}$ & & 8 & 8 & 8 & 8 & 10 \\
\hline Mineral mixt ${ }^{b}$ & & 4 & 4 & 4 & 4 & 4 \\
\hline Betaine & & 1 & 1 & 1 & 1 & 1 \\
\hline Dry Matter \% wet weight & & 94 & 92 & 92 & 92 & 92 \\
\hline $\mathrm{Nx} 6.25 \% \mathrm{DM}$ & & 57 & 57 & 54 & 51 & 46 \\
\hline Ash \%DM & & 14.1 & 14.2 & 13.7 & 8.6 & 8.8 \\
\hline Total lipid\% DMs & & 19.7 & 18.9 & 20.8 & 19.7 & 17.5 \\
\hline Polar lipids\% DM & & 11.0 & 10.7 & 11.1 & 10.4 & 7.6 \\
\hline
\end{tabular}

a Sources: Fish meal and cod liver oil : La Lorientaise (Lorient, France), Fish proteinhydrolysates: Sopropêche (Boulogne sur mer, France); Algamac : Aquafauna Biomarine (Hawthorne, Ca, USA); casein C7078, casein sodium salt C8654, casein hydrolysate NZ amine: C0626 Sigma; Soybean lecithin LPR: SAPA DADA S.D.A

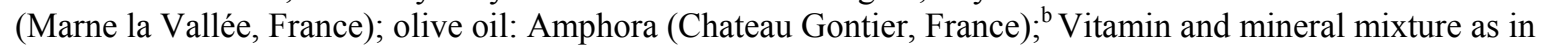
Fontagné et al. (2000). 
Table 2: Fatty acid composition (\% of total fatty acids) of dietary total and polar lipids.

\begin{tabular}{|c|c|c|c|c|c|c|c|c|c|c|}
\hline & \multicolumn{5}{|c|}{ Total lipids } & \multicolumn{5}{|c|}{ Polar lipids } \\
\hline & A & B & $\mathrm{C}$ & $\mathrm{D}$ & $\mathrm{E}$ & $\mathrm{A}$ & B & $\mathrm{C}$ & $\mathrm{D}$ & $\mathrm{E}$ \\
\hline 14:0 & 3.4 & 2.4 & 4.2 & 5.5 & 8.7 & 0.9 & 0.7 & 1.7 & 0.9 & 0.8 \\
\hline $16: 0$ & 16.6 & 16.8 & 20.2 & 21.1 & 25.2 & 25.5 & 24.1 & 28.1 & 27.0 & 31.8 \\
\hline 18:0 & 3.3 & 3.6 & 3.3 & 3.4 & 2.7 & 5.8 & 5.2 & 5.5 & 5.8 & 6.6 \\
\hline 20:0 & 0.2 & 0.2 & 0.2 & 0.2 & 0.2 & 0.2 & 0.2 & 0.2 & 0.2 & 0.2 \\
\hline $22: 0$ & 0.3 & 0.3 & 0.2 & 0.2 & 0.2 & 0.5 & 0.4 & 0.5 & 0.5 & 0.7 \\
\hline $14: 1$ & 0.2 & 0.3 & 0.1 & 0.5 & 0.3 & 0.2 & 0.1 & 0.0 & 0.0 & 0.0 \\
\hline $16: 1 n-7$ & 4.2 & 2.8 & 2.0 & 2.4 & 3.4 & 1.0 & 0.6 & 1.0 & 0.6 & 0.5 \\
\hline $18: 1 n-7$ & 2.7 & 2.5 & 2.2 & 2.1 & 2.1 & 1.5 & 1.6 & 1.6 & 1.5 & 1.6 \\
\hline $20: 1 n-7$ & 0.4 & 0.3 & 0.1 & 0.1 & 0.1 & 0.0 & 0.1 & 0.1 & 0.1 & 0.1 \\
\hline $18: 1 n-9$ & 10.5 & 20.0 & 27.0 & 23.1 & 14.6 & 7.3 & 10.1 & 9.3 & 9.6 & 7.6 \\
\hline $20: 1 n-9$ & 4.6 & 3.2 & 1.5 & 1.1 & 1.3 & 0.8 & 0.7 & 0.7 & 0.4 & 0.1 \\
\hline $22: 1 n-9$ & 0.7 & 0.5 & 0.2 & 0.2 & 0.2 & 0.0 & 0.1 & 0.0 & 0.0 & 0.0 \\
\hline $24: 1 n-9$ & 0.5 & 0.6 & 0.3 & 0.2 & 0.1 & 0.4 & 0.4 & 0.2 & 0.2 & 0.0 \\
\hline $18: 1 n-11$ & 1.1 & 0.6 & 0.0 & 0.0 & 0.4 & 0.0 & 0.0 & 0.0 & 0.0 & 0.1 \\
\hline $20: 1 n-11$ & 0.9 & 0.5 & 0.3 & 0.3 & 0.0 & 0.1 & 0.2 & 0.1 & 0.0 & 0.0 \\
\hline $22: 1 n-11$ & 5.5 & 3.7 & 1.5 & 1.1 & 1.4 & 0.2 & 0.4 & 0.4 & 0.2 & 0.1 \\
\hline $18: 2 n-6$ & 24.2 & 24.7 & 21.4 & 22.8 & 18.5 & 41.9 & 42.3 & 36.6 & 42.7 & 41.9 \\
\hline $18: 3 n-6$ & 0.2 & 0.1 & 0.1 & 0.1 & 0.1 & 0.1 & 0.1 & 0.0 & 0.1 & 0.0 \\
\hline $20: 2 n-6$ & 0.3 & 0.3 & 0.2 & 0.2 & 0.1 & 0.3 & 0.3 & 0.3 & 0.3 & 0.5 \\
\hline $20: 3 n-6$ & 0.1 & 0.1 & 0.0 & 0.1 & 0.1 & 0.0 & 0.1 & 0.0 & 0.0 & 0.0 \\
\hline $20: 4 n-6$ & 0.6 & 0.4 & 0.2 & 0.3 & 0.2 & 0.2 & 0.4 & 0.2 & 0.2 & 0.0 \\
\hline $22: 5 n-6$ & 0.3 & 0.1 & 1.6 & 1.8 & 3.2 & 0.4 & 0.4 & 1.1 & 0.8 & 0.8 \\
\hline $18: 3 n-3$ & 3.5 & 3.2 & 2.7 & 2.8 & 2.3 & 5.8 & 5.0 & 4.4 & 5.0 & 4.8 \\
\hline $18: 4 n-3$ & 1.3 & 1.0 & 0.3 & 0.4 & 0.6 & 0.2 & 0.2 & 0.1 & 0.0 & 0.1 \\
\hline $20: 3 n-3$ & 0.1 & 0.1 & 0.1 & 0.0 & 0.0 & 0.0 & 0.1 & 0.0 & 0.1 & 0.0 \\
\hline $20: 4 n-3$ & 0.5 & 0.3 & 0.2 & 0.2 & 0.3 & 0.1 & 0.1 & 0.1 & 0.0 & 0.0 \\
\hline $20: 5 n-3$ & 7.3 & 4.9 & 1.9 & 2.1 & 2.6 & 1.6 & 1.9 & 1.4 & 0.7 & 0.1 \\
\hline $22: 5 n-3$ & 0.8 & 0.5 & 0.2 & 0.3 & 0.3 & 0.4 & 0.3 & 0.4 & 0.3 & 0.4 \\
\hline $22: 6 n-3$ & 5.7 & 6.0 & 7.5 & 7.5 & 10.8 & 3.1 & 4.2 & 5.5 & 3.0 & 0.9 \\
\hline DHA/EPA & 0.8 & 1.2 & 3.9 & 3.6 & 4.2 & 1.9 & 2.2 & 4.0 & 4.2 & 15.3 \\
\hline n-3 HUFA $\% D M$ & 2.0 & 1.5 & 1.5 & 1.4 & 1.7 & & & & & \\
\hline
\end{tabular}

\subsection{Analysis}

Composition analyses of diets were made following standard methods: dry matter after desiccation in an oven $\left(105^{\circ} \mathrm{C}\right.$ for $\left.24 \mathrm{~h}\right)$, ash (incineration at $550^{\circ} \mathrm{C}$ for $12 \mathrm{~h}$ ), crude protein (Dumas, Nitrogen Analyser, Fison instrument, $\mathrm{N} \times 6.25$ ), lipids were extracted and quantified according to Folch et al. (1957), separation of polar and neutral lipids was performed according to Juaneda and Roquelin (1985). For lipid analyses of larva, an internal standard 
(tricosanoic acid 23:0) was added, on a sample of known quantity of larvae, then extraction was done according to Folch et al. (1957). A part of each sample (1 mg) was transmethylated according to Morrison and Smith (1964) for total fatty content, with $2 \mathrm{ml}$ of (1:1:1) methanol: toluene: $10 \% \mathrm{BF}_{3}$-methanol. All glassware used for extraction and transmethylation were heated at $550^{\circ} \mathrm{C}$ in an oven over night, before use. Fatty acid methyl esters were separated by gas chromatography as descrived previouly in Regost et al. (2002). The results of individual FA composition were quantified for each fatty acid, respectively, to the area of the internal standard and divided by the number of larvae analysed. A reference sample of cod liver oil transmetylated with the internal standard was regularly injected to control the regularity of the quantitative responses.

\subsection{Calculation and Statistical analysis:}

Comparisons of effects of dietary treatments were performed by one way ANOVA, significant differences $(\mathrm{P}<0.05)$ between means were compared by the Newman-Keuls test. Data on survival and fatty acid percentages were transformed by arcsinus of square root before applying ANOVA. Incorporation of fatty acids was computed for each final sample as quantity of each fatty acid per larvae minus mean initial value per larvae before feeding. From these data, relative raw incorporation was calculated for each fatty acid in percent of total fatty acids increase per larvae. Non-parametric sign-test (Dagnelie, 1969) was used to compare fatty acid percentages (relative incorporation minus percentage in diets) in order to check preferential incorporation of fatty acids common to various dietary treatments.

\section{Results}

Observation of gut contents of larvae showed a relatively good acceptance of the particulate diets. No clear differences were observed among treatments, except at day 5 where low ingestion was observed in treatment $\mathrm{A}$. 
Final growth and survival are reported in Table 3. Survival was significantly higher in larvae fed diet E, than treatments A, B, D, treatment C being intermediate. Daily count of dead larvae (Figure 1) indicates that most mortalities occurred from day 4 to day 6 post hatching, and near the end of experiment (17-21 dph). However in treatment A higher mortality occurred in the first period. Dead larvae counted during the course of the experiment represented only a part of those disappearing, thus these data has only relative value.

Table 3 : Final length, wet weight, dry weight and survival (mean $\pm \mathrm{SE}, \mathrm{n}=3$ )) of larva fed the various inert diets

\begin{tabular}{lccccc}
\hline Treatment & $\mathrm{A}$ & $\mathrm{B}$ & $\mathrm{C}$ & $\mathrm{D}$ & $\mathrm{E}$ \\
\hline length $\mathrm{mm}$ & $4.6 \pm 0.1^{\mathrm{a}}$ & $4.3 \pm 0.2^{\mathrm{ab}}$ & $4.6 \pm 0.2^{\mathrm{a}}$ & $4.2 \pm 0.1^{\mathrm{b}}$ & $4.2 \pm 0.1^{\mathrm{b}}$ \\
Wet weight $\mu \mathrm{g}$ & $350 \pm 25^{\mathrm{a}}$ & $325 \pm 2^{\mathrm{a}}$ & $343 \pm 3^{\mathrm{a}}$ & $264 \pm 12^{\mathrm{b}}$ & $292 \pm 22^{\mathrm{b}}$ \\
Dry weight $\mu \mathrm{g}$ & $65 \pm 13$ & $51 \pm 3$ & $66 \pm 2$ & $56 \pm 10$ & $64 \pm 6$ \\
Survival $\%$ & $7 \pm 1^{\mathrm{b}}$ & $7 \pm 3^{\mathrm{b}}$ & $14+3^{\mathrm{ab}}$ & $9 \pm 2^{\mathrm{b}}$ & $25 \pm 7^{\mathrm{a}}$ \\
\hline
\end{tabular}

Values are means \pm SE $(n=3)$.

Values in the same row with different superscripts are significantly different $(\mathrm{P}<0.05)$.

Figure 1: Daily mortalities (mean per treatment) in relative amount (daily counted dead larva\% of cumulated mortality per tank).

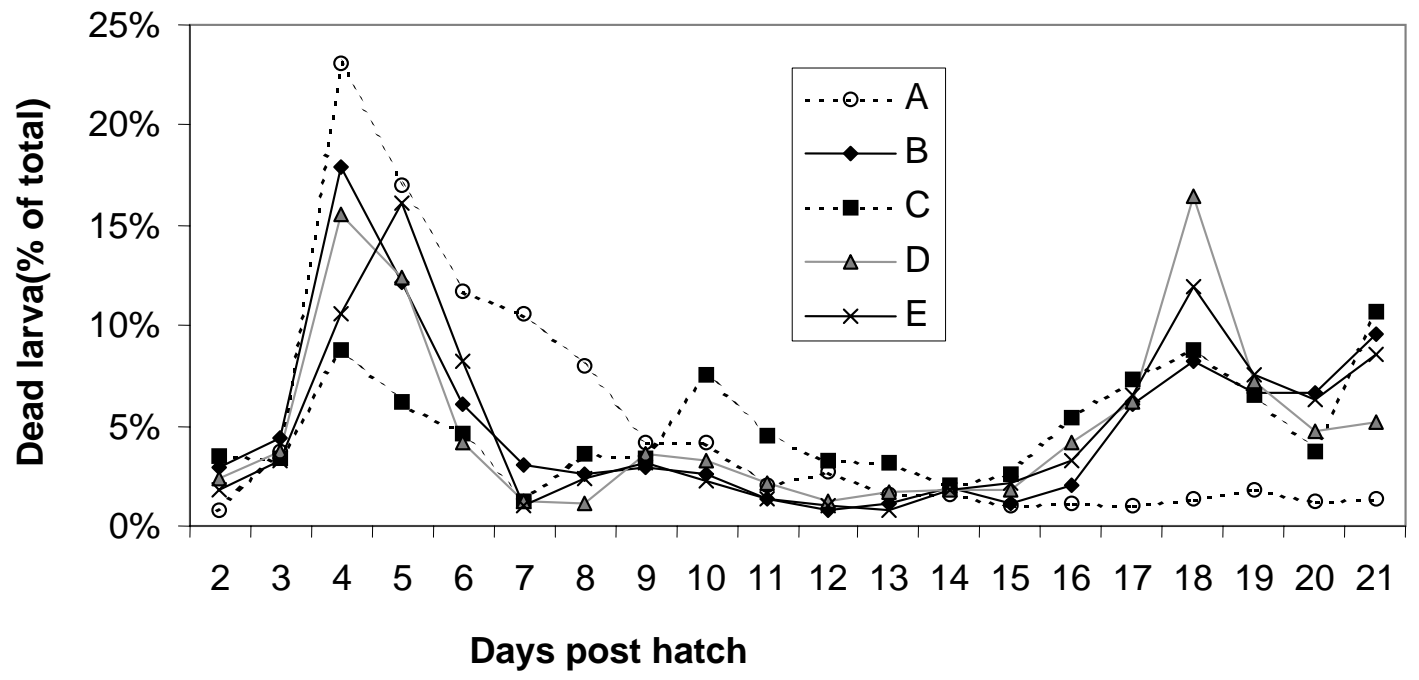


Significant lower growth was obtained with diets D and E on the basis of size; treatment B being intermediate. Estimation of growth as wet weight (formalin) followed the same tendencies, treatment $\mathrm{D}$ being significantly lower than other treatments and treatment $\mathrm{E}$ being intermediate. A significant correlation $(\mathrm{P}<0.01)$ can be drawn between these two measures, but they did not correlate with dry weight. Measures in dry weight did not give significant differences among treatments, however all of them increased compared to larvae before feeding $\left(28 \mu\right.$ g.larvae $\left.{ }^{-1}\right)$.

As shown in Table 4, the total fatty acid content of larvae differed among treatments and was not related to their respective growth. Compared to initial larva all treatment had a significantly higher fatty acid quantity per larvae, showing effective incorporation, however with diet $\mathrm{B}$ it represented less than twice the initial quantity, and less than three times in larva fed diets $\mathrm{A}$ and $\mathrm{C}$. A high quantity of lipids was observed in larvae fed diet E, followed by those fed diet D (casein plus fish autolysate). In treatments A and B survival was very low in one tank of each of these treatments, there was very few remaining larva, so only two replicates were analysed in these treatments. 
Table 4. Total fatty acid content in $\mu \mathrm{g}$.larva ${ }^{-1}$ and fatty acid composition (percent of total fatty acids) of larva before feeding ( $3 \mathrm{dph})$ and fed with the inert diets $(21 \mathrm{dph})$.

\begin{tabular}{|c|c|c|c|c|c|c|}
\hline & initial & $\mathrm{A}$ & $\mathrm{B}$ & $\mathrm{C}$ & $\mathrm{D}$ & $\mathrm{E}$ \\
\hline $\mathrm{tFA} \mu \mathrm{g} .1^{-1}$ & $3.9 \pm 0.1 \mathrm{e}$ & $10.9 \pm 0.7 \mathrm{c}$ & $6.5 \pm 0.1 \mathrm{~d}$ & $10.9 \pm 0.6 \mathrm{c}$ & $15.0 \pm 0.7 \mathrm{~b}$ & $19.8 \pm 0.8 \mathrm{a}$ \\
\hline \multicolumn{7}{|l|}{$\mathrm{FA} \%$} \\
\hline $14: 0$ & $4.8 \pm 0.3 \mathrm{a}$ & $2.5 \pm 0.4 \mathrm{c}$ & $1.7 \pm 0.1 \mathrm{c}$ & $1.8 \pm 0.0 \mathrm{c}$ & $2.3 \pm 0.2 \mathrm{c}$ & $3.5 \pm 0.0 \mathrm{~b}$ \\
\hline $16: 0$ & $20.1 \pm 0.2 \mathrm{a}$ & $17.5 \pm 0.2 \mathrm{~b}$ & $18.2 \pm 0.2 \mathrm{~b}$ & $17.9 \pm 0.2 \mathrm{~b}$ & $16.9 \pm 0.1 \mathrm{c}$ & $17.7 \pm 0.2 \mathrm{~b}$ \\
\hline $18: 0$ & $5.2 \pm 0.1 \mathrm{~d}$ & $7.1 \pm 0.1 \mathrm{~b}$ & $8.6 \pm 0.2 \mathrm{a}$ & $6.9 \pm 0.0 \mathrm{~b}$ & $5.8 \pm 0.1 \mathrm{c}$ & $5.0 \pm 0.0 \mathrm{e}$ \\
\hline $16: 1 n-7$ & $5.5 \pm 0.2 \mathrm{a}$ & $2.3 \pm 0.0 \mathrm{c}$ & $1.2 \pm 0.0 \mathrm{e}$ & $1.2 \pm 0.1 \mathrm{e}$ & $1.8 \pm 0.0 \mathrm{~d}$ & $2.7 \pm 0.0 \mathrm{~b}$ \\
\hline $18: 1 n-7$ & $2.8 \pm 0.0 \mathrm{a}$ & $2.7 \pm 0.1 \mathrm{a}$ & $2.3 \pm 0.0 \mathrm{~b}$ & $2.2 \pm 0.0 \mathrm{~b}$ & $2.2 \pm 0.0 \mathrm{~b}$ & $2.3 \pm 0.0 \mathrm{~b}$ \\
\hline $18: 1 n-9$ & $12.3 \pm 0.4 \mathrm{~d}$ & $9.0 \pm 0.1 \mathrm{e}$ & $13.6 \pm 0.4 \mathrm{c}$ & $20.3 \pm 0.5 \mathrm{a}$ & $20.5 \pm 0.3 \mathrm{a}$ & $15.2 \pm 0.3 \mathrm{~b}$ \\
\hline $20: 1 n-9$ & $0.9 \pm 0.1 \mathrm{~d}$ & $3.0 \pm 0.1 \mathrm{a}$ & $1.7 \pm 0.1 \mathrm{~b}$ & $1.1 \pm 0.1 \mathrm{c}$ & $0.9 \pm 0.0 \mathrm{~d}$ & $0.9 \pm 0.0 \mathrm{~d}$ \\
\hline $18: \ln -11$ & $0.3 \pm 0.3 \mathrm{~b}$ & $0.9 \pm 0.1 \mathrm{a}$ & $0.0 \pm 0.0 \mathrm{c}$ & $0.0 \pm 0.0 \mathrm{c}$ & $0.0 \pm 0.0 \mathrm{c}$ & $0.4 \pm 0.0 \mathrm{ab}$ \\
\hline $22: \ln -11$ & $0.3 \pm 0.1 \mathrm{c}$ & $3.2 \pm 0.0 \mathrm{a}$ & $1.5 \pm 0.2 \mathrm{~b}$ & $1.0 \pm 0.0 \mathrm{~b}$ & $0.7 \pm 0.0 \mathrm{~b}$ & $0.9 \pm 0.0 \mathrm{~b}$ \\
\hline $18: 2 n-6$ & $2.2 \pm 0.0 \mathrm{e}$ & $19.4 \pm 0.3 \mathrm{~cd}$ & $18.7 \pm 0.2 \mathrm{~d}$ & $20.0 \pm 0.2 \mathrm{c}$ & $23.7 \pm 0.2 \mathrm{a}$ & $20.7 \pm 0.4 b$ \\
\hline $18: 3 n-6$ & $0.1 \pm 0.1$ & $0.2 \pm 0.1$ & $0.1 \pm 0.0$ & $0.1 \pm 0.0$ & $0.1 \pm 0.0$ & $0.1 \pm 0.0$ \\
\hline $20: 2 n-6$ & $0.9 \pm 0.1 \mathrm{a}$ & $0.6 \pm 0.1 \mathrm{~b}$ & $0.8 \pm 0.0 \mathrm{a}$ & $0.5 \pm 0.0 \mathrm{bc}$ & $0.4 \pm 0.0 \mathrm{~cd}$ & $0.3 \pm 0.0 \mathrm{~d}$ \\
\hline $20: 3 n-6$ & $0.1 \pm 0.1$ & $0.1 \pm 0.0$ & $0.1 \pm 0.0$ & $0.1 \pm 0.0$ & $0.1 \pm 0.0$ & $0.1 \pm 0.0$ \\
\hline $20: 4 n-6$ & $1.5 \pm 0.1 \mathrm{a}$ & $1.4 \pm 0.0 \mathrm{a}$ & $1.5 \pm 0.0 \mathrm{a}$ & $1.0 \pm 0.0 \mathrm{~b}$ & $0.9 \pm 0.0 \mathrm{c}$ & $0.8 \pm 0.0 \mathrm{~d}$ \\
\hline $22: 5 n-6$ & $0.4 \pm 0.0 \mathrm{e}$ & $0.4 \pm 0.0 \mathrm{de}$ & $0.5 \pm 0.1 \mathrm{~d}$ & $2.9 \pm 0.0 \mathrm{~b}$ & $2.6 \pm 0.0 \mathrm{c}$ & $4.7 \pm 0.0 \mathrm{a}$ \\
\hline $18: 3 n-3$ & $0.4 \pm 0.0 \mathrm{e}$ & $1.9 \pm 0.0 \mathrm{~b}$ & $1.3 \pm 0.1 \mathrm{~d}$ & $1.6 \pm 0.0 \mathrm{c}$ & $2.3 \pm 0.1 \mathrm{a}$ & $2.1 \pm 0.0 \mathrm{~b}$ \\
\hline $18: 4 n-3$ & $0.5 \pm 0.0 \mathrm{a}$ & $0.6 \pm 0.0 \mathrm{a}$ & $0.3 \pm 0.1 \mathrm{~b}$ & $0.2 \pm 0.1 \mathrm{~b}$ & $0.3 \pm 0.0 \mathrm{~b}$ & $0.5 \pm 0.0 \mathrm{a}$ \\
\hline $20: 3 n-3$ & $0.4 \pm 0.1 \mathrm{a}$ & $0.1 \pm 0.1 \mathrm{~b}$ & $0.1 \pm 0.0 \mathrm{~b}$ & $0.1 \pm 0.0 \mathrm{~b}$ & $0.1 \pm 0.0 \mathrm{~b}$ & $0.1 \pm 0.0 \mathrm{~b}$ \\
\hline $20: 4 n-3$ & $0.5 \pm 0.0 \mathrm{a}$ & $0.4 \pm 0.0 \mathrm{~b}$ & $0.2 \pm 0.0 \mathrm{~d}$ & $0.2 \pm 0.0 \mathrm{~d}$ & $0.2 \pm 0.0 \mathrm{~d}$ & $0.3 \pm 0.0 \mathrm{c}$ \\
\hline $20: 5 n-3$ & $7.3 \pm 0.1 \mathrm{a}$ & $7.2 \pm 0.1 \mathrm{~b}$ & $5.0 \pm 0.1 \mathrm{c}$ & $2.5 \pm 0.1 \mathrm{e}$ & $2.4 \pm 0.0 \mathrm{e}$ & $3.2 \pm 0.0 \mathrm{~d}$ \\
\hline $22: 5 n-3$ & $2.6 \pm 0.1 \mathrm{a}$ & $1.5 \pm 0.1 \mathrm{~b}$ & $1.1 \pm 0.0 \mathrm{c}$ & $0.4 \pm 0.0 \mathrm{~d}$ & $0.5 \pm 0.0 \mathrm{~d}$ & $0.5 \pm 0.0 \mathrm{~d}$ \\
\hline $22: 6 n-3$ & $30.1 \pm 0.4 \mathrm{a}$ & $15.1 \pm 0.3 \mathrm{e}$ & $19.7 \pm 0.8 b$ & $16.6 \pm 0.3 \mathrm{~d}$ & $13.6 \pm 0.3 \mathrm{f}$ & $17.7 \pm 0.1 \mathrm{c}$ \\
\hline
\end{tabular}

Values are means $\pm \mathrm{SE}$ ( $\mathrm{n}=2$ for $\mathrm{A}$ and $\mathrm{B} ; \mathrm{n}=3$ for C.D.E), minor saturates and monoenes omitted were not significant.

Values in the same row with different superscripts are significantly different $(\mathrm{P}<0.05)$.

All diets induced high linoleic (18:2n-6) content in larvae, at a level relatively close to overall percentages in the diets, but the differences among treatments were not related to dietary levels. Similar comments can be made for various other fatty acids. DHA content was reduced compared to initial larva, but was high compared to the content in the diets. Larvae fed diets containing algamac $(\mathrm{C}, \mathrm{D}, \mathrm{E})$ had higher DHA/EPA ratios and 22:5n-6 content, compared to those fed diets $\mathrm{A}$ and $\mathrm{B}$, but were lower in arachidonic acid (20:4n-6), in accordance to dietary fatty acids.

To follow more precisely dietary fatty acid influence, the raw incorporation of fatty acids into larva was calculated for each sample. Direct results are not presented here as quantities of each fatty acid into larva were mainly dependant of total fatty acid incorporated per larvae, 
which differed among treatments. Then in order to have comparable presentation of fatty acids, relative incorporation spectra were calculated by dividing each quantity fatty acids by the corresponding total fatty acid content per larva (Table 5), and that can be compared to the dietary fatty acid profile.

The fatty acid profile incorporated into larvae was only relatively similar to that of diets. Remarkable differences can be observed, occurring in the same way under the various treatments. Some fatty acid incorporation was lower or higher than their corresponding values in diets as shown by a sign-test. The incorporation of 18:2n-6 was higher than its relative proportion in diets. Larvae fed diet B incorporated this fatty acid at the highest level. Incorporation of 20:4 n-6 was 2 to 4 fold higher than the ratio in diets (whatever the level of 22:5n-6 was). Other n-6 fatty acids were incorporated positively as 22:5, also 20:2 and 20:3 but the two latter represented very low levels. Relatively high incorporation of 18:0 (stearic acid) also occurred. Other fatty acids were incorporated in low amounts compared to dietary levels. Some of them, such as 14:0, 16:1n-7, 18:1n-11 and minor n-3 fatty acids, showed negative incorporation into larva having low total FA increases. EPA and 16:0 were incorporated at significantly lower rates into larvae compared to dietary levels. 22:6n-3 was incorporated at a ratio higher than diets in 9 samples, and lower in 4 others, then a preference for DHA incorporation was not significant $(\mathrm{P}=0.13)$. 
Table 5 : Relative fatty acid incorporation (\% of total fatty acid incorporated $)^{\mathrm{a}}$ in larvae fed the various diets and comparison to dietary total fatty acid composition by a sign-test (S.T.)

\begin{tabular}{|c|c|c|c|c|c|c|}
\hline Treatment & A & $\mathrm{B}$ & $\mathrm{C}$ & $\mathrm{D}$ & $\mathrm{E}$ & S.T. \\
\hline $14: 0$ & $1.3 \pm 0.5$ & $-2.9 \pm 0.0$ & $0.2 \pm 0.2$ & $1.4 \pm 0.3$ & $3.3 \pm 0.1$ & $* *_{-} \mathrm{b}$ \\
\hline $16: 0$ & $16.1 \pm 0.1$ & $15.4 \pm 0.3$ & $16.6 \pm 0.3$ & $15.7 \pm 0.2$ & $17.1 \pm 0.2$ & $* *_{-}$ \\
\hline 18:0 & $8.2 \pm 0.0$ & $13.5 \pm 0.7$ & $7.9 \pm 0.2$ & $6.1 \pm 0.1$ & $4.9 \pm 0.0$ & $* *+$ \\
\hline $16: 1 n-7$ & $0.5 \pm 0.1$ & $-5.1 \pm 0.3$ & $-1.2 \pm 0.1$ & $0.5 \pm 0.1$ & $2.1 \pm 0.1$ & $* *_{-}$ \\
\hline $18: 1 n-7$ & $2.7 \pm 0.1$ & $1.5 \pm 0.1$ & $1.9 \pm 0.1$ & $2.0 \pm 0.0$ & $2.2 \pm 0.0$ & \\
\hline $18: 1 n-9$ & $7.1 \pm 0.4$ & $15.5 \pm 0.9$ & $24.7 \pm 0.7$ & $23.4 \pm 0.3$ & $16.0 \pm 0.4$ & \\
\hline $20: 1 n-9$ & $4.2 \pm 0.3$ & $2.8 \pm 0.2$ & $1.3 \pm 0.1$ & $0.9 \pm 0.0$ & $0.9 \pm 0.0$ & $* *_{-}$ \\
\hline $18: \ln -11$ & $1.2 \pm 0.0$ & $-0.4 \pm 0.0$ & $-0.1 \pm 0.0$ & $-0.1 \pm 0.0$ & $0.4 \pm 0.0$ & $* *_{-}$ \\
\hline $20: 1 n-11$ & $1.0 \pm 0.2$ & $0.6 \pm 0.1$ & $0.2 \pm 0.1$ & $0.2 \pm 0.0$ & $0.1 \pm 0.1$ & \\
\hline $22: 1 n-11$ & $4.8 \pm 0.2$ & $3.2 \pm 0.3$ & $1.3 \pm 0.1$ & $0.9 \pm 0.0$ & $1.1 \pm 0.0$ & $* *_{-}$ \\
\hline $18: 2 n-6$ & $28.9 \pm 0.5$ & $43.1 \pm 0.3$ & $29.9 \pm 0.6$ & $31.3 \pm 0.6$ & $25.3 \pm 0.7$ & $* *+$ \\
\hline $18: 3 n-6$ & $0.2 \pm 0.1$ & $0.1 \pm 0.1$ & $0.1 \pm 0.0$ & $0.1 \pm 0.0$ & $0.1 \pm 0.0$ & \\
\hline $20: 2 n-6$ & $0.4 \pm 0.1$ & $0.7 \pm 0.1$ & $0.3 \pm 0.1$ & $0.2 \pm 0.0$ & $0.2 \pm 0.0$ & $*+$ \\
\hline $20: 3 n-6$ & $0.1 \pm 0.0$ & $0.1 \pm 0.0$ & $0.1 \pm 0.0$ & $0.1 \pm 0.0$ & $0.1 \pm 0.0$ & $* *+$ \\
\hline $20: 4 n-6$ & $1.4 \pm 0.1$ & $1.6 \pm 0.1$ & $0.7 \pm 0.0$ & $0.7 \pm 0.0$ & $0.6 \pm 0.0$ & $* *+$ \\
\hline $22: 5 n-6$ & $0.4 \pm 0.0$ & $0.8 \pm 0.3$ & $4.3 \pm 0.2$ & $3.4 \pm 0.1$ & $5.8 \pm 0.1$ & $* *+$ \\
\hline $18: 3 n-3$ & $2.8 \pm 0.1$ & $2.6 \pm 0.1$ & $2.4 \pm 0.0$ & $3.0 \pm 0.1$ & $2.5 \pm 0.1$ & \\
\hline $18: 4 n-3$ & $0.7 \pm 0.1$ & $0.1 \pm 0.2$ & $0.1 \pm 0.1$ & $0.2 \pm 0.0$ & $0.5 \pm 0.0$ & $* *_{-}$ \\
\hline $20: 3 n-3$ & $-0.1 \pm 0.2$ & $-0.3 \pm 0.1$ & $-0.1 \pm 0.0$ & $-0.0 \pm 0.0$ & $-0.0 \pm 0.0$ & $* *_{-}$ \\
\hline $20: 4 n-3$ & $0.3 \pm 0.0$ & $-0.2 \pm 0.0$ & $-0.0 \pm 0.0$ & $0.1 \pm 0.0$ & $0.2 \pm 0.0$ & $* *_{-}$ \\
\hline $20: 5 n-3$ & $7.2 \mathrm{c} \quad 0.2$ & $1.6 \pm 0.3$ & $-0.2 \pm 0.3$ & $0.7 \pm 0.1$ & $2.2 \pm 0.1$ & $* *_{-}$ \\
\hline $22: 5 n-3$ & $0.9 \pm 0.2$ & $-1.0 \pm 0.0$ & $-0.8 \pm 0.1$ & $-0.3 \pm 0.0$ & $-0.0 \pm 0.0$ & $* *_{-}$ \\
\hline $22: 6 n-3$ & $6.8 \pm 1.3$ & $4.5 \pm 1.3$ & $9.1 \pm 0.4$ & $7.8 \pm 0.4$ & $14.7 \pm 0.2$ & \\
\hline
\end{tabular}

${ }^{\mathrm{a}}$ Values are means \pm SE ( $\mathrm{n}=2$ for $\mathrm{A}$ and $\mathrm{B} ; \mathrm{n}=3$ for C.D.E), minor saturates and monoenes omitted were not significant.

${ }^{\mathrm{b}}$ Sign-test given common relative incorporation higher $(+)$ or lower $(-)$ than corresponding dietary fatty acid when significant occurrence: $\mathrm{P}<\alpha / 2{ }^{*} \alpha=0.05 ; * * \alpha=0.01$.

\section{Discussion}

Due to their initial endotrophic nutrition phase, larvae first have growth in size and wet weight, even during fasting. For that reason, dry weight is a good criteria to measure growth in short time experiments. All tested diets gave an effective increase in dry weight, significantly different than initial larvae before feeding. However their growth was very low compared to what could be obtained with live food. Yúfera et al. (2000) failed to obtain effective growth by using microcapsules as first food, while they obtained higher growth rate than here when microcapsules were fed to larvae after a few days of being fed on Brachionus plicatilis. 
Growth in length, can be related to dietary protein source, diets containing fish meal gave better growth than diets $\mathrm{D}$ and $\mathrm{E}$, while diet $\mathrm{B}$ was intermediate. Results in wet weight followed the same tendency but only diet D gave a significantly lower value. Increase in size and in wet weight were relatively well correlated, but not with dry weight. It seems that dry weight was depend of both growth in size and lipid content, measured by total fatty acids. Higher lipid content was observed in larva fed diets E and D containing casein as the main protein source, despite the lower dietary lipids in diet E. These two diets also resulted in low growth in size. Casein is not a good source of protein for fish, less than fish meal (Rumsey and Ketola, 1975). The use of soluble protein, together with native casein, increases protein utilization by carp larva (Carvalho et al, 1997; 2001). It seems that casein, even with soluble proteins, induced a limited growth, in the current study, but increased energy storage into lipid compared to the fish meal based diets. The level of essential fatty acids HUFA n-3, used in this experience was supposed to be sufficient as previously controlled in an unpublished experiment. Rodriguez et al. (1998) reported a dietary requirement of n-3 HUFA at 1.5\% DW, with DHA/EPA around 2, for gilthead sea bream larvae when using rotifers as food. No difference in growth was observed in the present experiment between diets A or B (DHA/EPA 0.8, 1.2) and diet C (DHA/EPA=3.9).

Survival were higher with diets $\mathrm{E}$ and $\mathrm{C}$, the result being significant only for larva fed diet $\mathrm{E}$, compared to the other treatments. These diets contained algamac $\AA$, a Schizochytrium powder, this product could have a beneficial effect on survival. However, diet D also contained algamac ${ }^{\circledR}$ and resulted in a mean survival rate close to that obtained with diets $\mathrm{A}$ and $\mathrm{B}$. Algamac $($ is rich in DHA, leading to an increased DHA/EPA ratio. Increasing the DHA/EPA ratio in enriched live prey results in improved larval survival (Watanabe 1993). DHA also has an effect on stress tolerance (Kanazawa, 1997). Various ingredients of Algamac ${ }^{\circledR}$ could be involved in survival improvement. Several studies have shown a beneficial effect of 
microalgae on larval rearing, including triggering of digestive enzymes (Cahu et al., 1998). Other non dietary factors may also interfere with survival, as a negative effect of bacteria developing into tanks enhanced by the particulate diets (Gatesoupe et al., 1997).

In the present experiment, larva fed the various diets were in different physiological status based on growth, survival and lipid content. Mean growth was also low. The fatty acid profiles observed in Table 4 have been influenced by the initial fatty acid content, at least for treatments having the lowest rate of fatty acid increase. That is why relative incorporation of fatty acids was calculated in order to observe if such data transformation might give additional information. That was the case. For DHA (22:6n-3), the direct observation of fatty acid profile showed intermediate values for DHA between initial larva and diets. However, calculation of relative incorporations indicated that DHA was not well retained, at least for diets $\mathrm{A}$ and $\mathrm{D}$. Also the increase in DHA/EPA ratio in larvae seemed to be due to a low incorporation of EPA. Direct fatty acid pattern showed high level of 18:2n-6. This fatty acid was incorporated in a higher ratio than presence in diets. Linoleic acid was the main fatty acid in dietary polar lipid. A higher incorporation of fatty acids originating from polar lipids than from triglycerides was observed by Izquierdo et al. (2001). Presence of DHA and EPA in dietary polar lipid did not seem to have influence on n-3 HUFAs incorporation into larvae, the highest incorporation occurred with the diet E, having no n-3 HUFA in polar lipid.

Of course, in this kind of study the term incorporation must be taken carefully as it results from various influences. Digestibility of diets and fatty acids cannot be measured in these larva, some saturates and monoenes are known to be poorly digested (Ringø and Olsen, 1991). A higher raw incorporation, may be influenced by preferential incorporation of a fatty acid, as well as preferential utilisation of others for energy production, or transformation of precursors via an elongation/desaturation pathway. In the present study, a higher incorporation index of 18:0 together with low values for 14:0 and 16:0 could be due to 
elongations, as well as to higher $\beta$-oxidation of 14:0 and 16:0 compare to 18:0 (Henderson and Sargent, 1983; Kiessling and Kiessling, 1993). The increase of DHA/EPA ratio in larvae compared to diets could be regarded as a possible result of production of DHA from EPA; such conversion occurs in starved gilthead sea bream juveniles (Mourente and Tocher, 1994), while Mourente at al. (1993) considered that dietary EPA could not contribute significantly to tissue DHA levels in larval gilthead sea bream. Some desaturation activity is possible in gilthead sea bream, while generally very low in marine fish compared to salmonids (Kanazawa, 1985). Tocher and Ghioni (1999) shows a $\Delta 6$ desaturase activity, but very low $\Delta 5$ desaturation in gilthead seam bream cell lines, leading to some accumulation of $18: 3 n-6$ and $20: 3 n-6$ when $18: 2 n-6$ was added, or $18: 4 n-3$ and $20: 4 n-3$ when $18: 3 n-3$ was added to the culture medium. However desaturase activities are decreased in HUFA supplemented salmon cell culture compared to EFA deficient ones (Ruyter and Thomassen, 1999); gilthead sea bream desaturase seems to be highly depressed by dietary HUFAs (Seliez, com. pers.). Direct observation of fatty acids profiles did not show accumulation of intermediate fatty acids of the $n-3$ or $n-6$ elongation and desaturation pathways in the present study despite high dietary 18:2n-6. Relative incorporation seemed to be positive for $n-6$, and negative for $n-3$ intermediate fatty acids, but values remained very low. Relative arachidonic acid incorporation in larva was high relatively to dietary content: it represented 4 times the content of diet $\mathrm{A}$ and $\mathrm{B}(0.6 \%)$, and 2 to 3 fold the content of diets $\mathrm{C}, \mathrm{D}$ and $\mathrm{E}(0.2 \%)$ containing algamac. Despite the presence of $22: 5 n-6$ in diets $C, D$ and $E$, and the high quantities of 18:2n-6 in all diets, the incorporation of 20:4n-6 seemed mainly determined by dietary levels. When algamac $\AA$ is use as an enrichment of live prey offered to larvae, it is a source of arachidonic acid, as live prey convert 22:5n-6 to 20:4n-6 (Barcley and Zeller,1996). Sargent et al. (1997) suggested that $22: 5 n-6$ could be chain shortened to $20: 4 n-6$ by larvae. The results obtained here show that gilthead sea bream larvae were not able to do this conversion. 
So this algae powder does not represent a way to supply arachidonic acid with inert diets as food. This fatty acid has beneficial effects for this species on larval performance (Bessonard et al.,1999), as well as on stress resistance (Koven et al., 2001).

Fish fatty acid content is said to reflect dietary fatty acid content, however differences between treatments were lower than those between diets (Hardy et al., 1987). In the present experiment there was less differences between composition of larvae compared to diets and mainly to relative incorporation. Diets used were relatively similar, characterised by high linolenic content. Larval growth and total fatty acid incorporation differed among treatments. As a result, only some of the observed differences among treatments could be related to the dietary differences as DHA/EPA ratio, arachidonic and 22:5n-6 contents. In contrast, DHA and linolenic acid seemed to be influenced by others factors.

\section{Acknowledgments}

This was supported as a part of EU project Q5RS-2000-30058 (RAFOA). The authors are grateful to J.-S. Bruan (FMD, La Brée les Bains, France) who provided spawn as a favour, to I. Seliez (INRA, St Pee sur Nivelle, France) and P. Quazuguel for their assistance, to P. Bergot (INRA, St Pee sur Nivelle, France) for sound advices, and to T. Sutherland for English corrections.

\section{References}

Barcley, W., Zeller S., 1996. Nutritionnal enhancement of n-3 and n-6 fatty acids in rotifers and Artemia by feeding spray-dried Schizochytrium. J. World Aquacult. Soc. 27, 314322. 
Bessonart, M., Izquierdo, M. S., Salhi, M., Hernández-Cruz, C. M., González, M. M., Fernández-Palacios, H., 1999. Effect of dietary arachidonic acid levels on growth and survival of gilthead sea bream (Sparus aurata L.) larvae. Aquaculture 179, 265-275.

Cahu, C.L., Zambonino-Infante, J.L., 2001. Substitution of live food by formulated diets in marine fish larvae. Aquaculture 200, 161-180.

Cahu, C., Zambonino-Infante, J.L., Péres, A., Quazuguel, P., Le Gall, M.M., 1998. Algal addition in sea bass (Dicentrarchus labrax) larvae rearing : effect on digestive enzymes. Aquaculture 161, 479-489.

Carvalho, A.P., Escaffre, A.-M., Oliva Teles, A., Bergot, P., 1997. First feeding of common carp larvae on diets with high levels of protein hydrolysates. Aquacult. Int. 5, 361-367.

Carvalho, A.P., Sa, R.M., Oliva Teles, A., Bergot, P., 2001. Importance of solubility and hydrolysis on utilization of dietary protein by carp (Cyprinus carpio) larvae. In: Hendry, C.I., Van Tappen, G., Wille, M., Sorgeloos, P. (Eds) Larvi'01, Fish and Shellfish Larviculture Symposium. EAS Spec. pub. 30, Ostende, Belgium, pp 108-110.

Dagnelie, P., 1969. Théorie et méthodes statistiques. Duculot J. (Ed) Gremloux France, vol 2, $63 \mathrm{pp}$.

Folch, J., Lees, M., Sloane-Stanley, G.H., 1957. A simple method for the isolation and purification of total lipids from animal tissues. J. Biol. Chem. 226, 497-509.

Fontagné, S., Robin, J., Corraze, G., Bergot, P., 2000. Growth and survival of European sea bass (Dicentrarchus labrax) larvae fed from first feeding on compound diets containing medium-chain triacylglycerols. Aquaculture 190, 261-271

Gatesoupe, F.J., Zambonino-Infante, J.L., Cahu, C., Quazuguel, P., 1997. Early weaning of seabass larvae, Dicentrarchus labrax: the effect on microbiota, with particular attention to iron supply and exoenzymes. Aquaculture 158, 117-127. 
Geurden I., Coutteaux P., Sorgeloos, P., 1995. Dietary phospholipids for European sea bass (Dicentrarchus labrax L.) during first ongrowing. In: Lavens, P., Jaspers E., Roelants, I. (Eds) Larvi 95'-Fish and shellfish Larviculture Symposium. EAS Spec. pub. 24, Gent, Belgium, pp175-178.

Hardy, R.W., Scott, T.M., Harrell, L.W., 1987. Replacement of herring oil with menhaden oil, soybean oil or tallow in the diet of Atlantic salmon raised in marine net pens. Aquaculture 65, 267-277.

Henderson, R.J., Sargent, J.R., 1983. Studies on the effects of di-(2-ethylhexyl) phthalate on lipid metabolismin rainbow trout (Salmo gairdnerii) fed zooplankton rich in wax esters. Comp. Biochem. Physiol. 74C, 325-330.

Izquierdo, M.S., Tandler, A., Salhi, M., Kolkovski, S., 2001. Influence of dietary polar lipid quantity and quality on ingestion and assimilation of labelled fatty acids by larval gilthead seabream. Aquacult. Nutr. 7, 153-160.

Juaneda, P., Rocquelin, G., 1985. Rapid and convenient separation of phospholipids and nonphosphorus lipids from rat heart using silica cartridges. Lipids 20, 40-41.

Kanazawa, A., 1985. Essential fatty acid and lipid requirement of fish. In: Cowey, C.B., Mackie, A.M., Bell, J.G. (Eds.) Nutrition and Feeding in Fish. Academic Press, London, pp. 281-298.

Kanazawa, A., 1993. Essential phospholipids of fish and crustaceans. In Kanshik, S.J.; Luquet, P. (Eds.), Fish Nutrition in Practice. INRA Colloq., no. 61, Paris, France, pp. $519-530$.

Kanazawa, A., 1997. Effects of docosahexanoic acid and phospholipids on stress tolerance of fish. Aquaculture 155, 129-134

Kiessling, K.-H., Kiessling, A., 1993. Selective utilization of fatty acids in rainbow trout (Oncorhynchus mykiss Walbaum) red muscle mitochondria. Can. J. Zool. 71, 248-251. 
Koven, W.M., Tandler, A., Kissil, G.W., Sklan, D., Friedzland, O., Harel M., 1990. The effect of dietary (n-3) polyunsaturated fatty acids on growth, survival and swim bladder development in Sparus aurata larvae. Aquaculture 91, 131-141.

Koven, W.M., Parra, G., Kolkowski, S., Tandler, A., 1998. The effect of dietary phosphatidylcholine and its constituent fatty acids on microdiet ingestion and fatty acid absorption rate in gilthead sea bream, Sparus aurata larvae. Aquacult. Nutr. 4, 39-45.

Koven, W., Kolkovski, S., Hadas, E., Gamsiz, K., Tandler A., 2001. Advances in the development of microdiets for gilthead seabream, Sparus aurata: a review. Aquaculture $194,107-121$.

Mourente, G., Tocher, D.R., 1994. In vivo metabolism of [1-14C]linolenic acid (18:3(n-3)) and [1-14C]eicosapentaenoic acid (20:5(n-3)) in marine fish: Time-course of the desaturation/elongation pathway. Biochim. Biophys. Acta 1212, 109-118.

Mourente, G., Rodriguez, A., Tocher, D.R., Sargent, J.R., 1993. Effects of dietary docosahexaenoic acid (DHA; 22:6n-3) on lipid and fatty acid compositions and growth in gilthead sea bream (Sparus aurata L.) larvae during first feeding. Aquaculture 112, 79-98.

Morrisson, W., Smith, L., 1964. Preparation of fatty acid methyl esters and dimethylacetals from lipids with boron fluoride-methanol. J. Lipid Res. 3 600-608

Regost, C., Arzel, J., Robin, J., Rosenlund, G., Kaushik, S.J., 2003. Total replacement of fish oil by soybean oil or linseed oil with return to fish oil in turbot (Psetta maxima). 1 growth performance, flesh fatty acid profile and lipid metabolism. Aquaculture 217, 191-199.

Ringø, E., Oslen, R.E., 1991. Do Artic charr, Salvelinus alpinus (L.) have selective absorption of dietary fatty acids? Fiskeridir. Skr. (Ernaering) 4, 65-72. 
Radünz-Neto, J., Corraze, G., Charlon, N., Bergot, P., 1994. Lipid supplementation of caseinbased purified diets for carp (Cyprinus carpio L.) larvae. Aquaculture 128, 153-161.

Rodriguez, C., Perez, J.A., Izquierdo, M.S., Mora, J., Fernandez-Palacios, H., Hernandez, A.L., 1993. Essential fatty acids requirements of larval gilthead sea bream (Sparus aurata L.). Aquacult. Fish. Manage. 24, 295-304.

Rodriguez, C., Perez, J.A., Badia, P., Izquierdo, M.S., Fernandez-Palacios, H., Hernandez, A.L., 1998. The n-3 highly unsaturated fatty acids requirements of gilthead sea bream (Sparus aurata L.) larvae when using an appropriate DHA/EPA ratio in the diet. Aquaculture169, 9-23.

Rumsey, G.L., and Ketola, F.G., 1975. Amino acid supplementation of casein diets of Atlzantic salmon (Salmo salar) fry and soybean meal for rainbow trout (Salmo gairdneri). J. Fish. Res. Board Can. 36, 422-426.

Ruyter, B., Thomassen, S., 1999. Metabolism of n-3 and n-6 fatty acids in Atlantic salmon liver: stimulation by essential fatty acid deficiency. Lipids 34, 1167-1176.

Salhi, M., Hernández-Cruz, C. M., Bessonart, M.,. Izquierdo M. S., Fernández-Palacios, H., 1999. Effect of different dietary polar lipid levels and different n-3 HUFA content in polar lipids on gut and liver histological structure of gilthead sea bream (Sparus aurata) larvae. Aquaculture 179, 253-263.

Sargent, J.R., Bell, J.G., Bell, M.V., Henderson, R.J., Tocher, D.R., 1997. Requirement, presentation and sources of polyunsaturated fatty acids in marine fish larval feeds. Aquaculture 155, 117-127.

Tocher, D.R., Ghioni, C., 1999. Fatty acid metabolism in marine fish: low activity of fatty acyl delta 5 desaturation in gilthead sea bream (Sparus aurata) cells. Lipids 34(5) 433440. 
Watanabe, T., 1993. Importance of docosahexanoic acid in marine larval fish. J. World Aquacult. Soc. 24, 151-161.

Yúfera, M., Fernandez-Diaz, C., Pascual, E., Sarasquete, M., Moyano, F., Diaz, M., Alarcon, F., Garcia-Gallego, M., Parra, G., 2000. Towards an inert diet for first-feeding gilthead sea bream Sparus aurata larvae. Aquacult. Nutr. 6, 143-152. 